\title{
(1) CPhysical Education \\ EFFECT OF YOGIC PRACTIES ON SELECTED HAEMOGLOBIN VARIABLES OF COLLEGE WOMEN STUDENTS
}

\section{Saradha*}

\section{A. Rajam}

R. P.

\section{Balasubramanian}

Sky Research Centre, WCSC, Aliyar, Pollachi Taluk, Coimbatore District, Tamilnadu, India. *Corresponding Author

Department Of Physical Education And Sports, Mother Teresa Women's University, Kodaikanal.624102, Tamilnadu, India.

Sky Research Centre, WCSC, Aliyar, Pollachi Taluk, Coimbatore District, Tamilnadu, India. students. To resolve the purpose of the study 40 college women were randomly selected from Kumaraguru College of Technology, Coimbatore. Their age ranged between 18 and 22 years. The selected subjects were randomly divided into two groups consisting of twenty each. No attempt was made to equate the groups. Experimental Group I underwent Yogic practices and Meditation for a period of 16 weeks. Group II acted as control group (CG) and were not engaged in any training programme other than their work. The subjects were free to withdraw their consent in case of feeling any discomfort during the period of their participation but there was no dropout during the study. The Haemoglobin variables were selected and tested through TCDC and Shalis blood analyzer test respectively. Pre and post tests were conducted in all the variables. 16 weeks of yogic practices were given to the experimental group for a period of 16 weeks. Dependent $t$ test was used to determine the significant difference between the treatment means. Yogic practice group had significantly increased Haemoglobin where as the control group had no significant increase in all the variables.

KEYWORDS : Yogic Practices, Meditation And Haemoglobin.

\section{INTRODUCTION}

The most important aim of our lives should be to maintain good health. Many people take their health for granted and abuse their bodies with a sedentary life style, bad diets, medications and high tension factors. Every person, due to genetic weaknesses, is susceptible to certain ailments that if not prevented can lead to serious illnesses. When energy is depleted in the body the organs become weak and they cannot function properly. The natural equilibrium will be disturbed and a disorder can develop. Genetic factors will dictate which particular disorder may develop and which organ might be affected. Some people may be prone to a certain condition such as diabetes, cancer, peptic ulcers and heart disease. Yoga acts preventive measures to disease by reducing stress level, keeping the internal organs toned and healthy and maintaining a balanced equilibrium between the physical, mental and spiritual level. The emphasis is to unite the system with a combination of breathing techniques, gentle exercise and mind control. This produces a tranquillity that penetrates deep into the mind and soul. It improves the health of the person on all levels. (VimalaLalvani, 2003)

Women who are employed play a vital and multiple roles. The need for a balance, both at home and work place is important. Women tend to be care givers and out of the sense of duty, they have a hard time justifying behaviour that are "just for themselves" such as exercise, recreation and relaxation (Fogoros, 2009).

Women with her multiple role in the family, career and society faces tremendous challenge in her everyday life. Increase in lifestyle standards, more of convenience food consumption and recreation with reduced physical activity has made women the victims for cardiovascular disease. The mortality rate among women suffering from cardiovascular disease is also higher than that of men across the world, including India (Roger and Menthal, 2006).

\section{YOGIC PRACTICES}

The word yoga derived from the Sanskrit root 'yuj' meaning to bind, join, attach and yoke, to direct and concentrate one's attention on, to use and apply. It also means union or communion. Yoga was collated, coordinate and systematized by Patanjali in his classical work, the yoga sutras, which consists of 185 terse aphorisms. (Iyengar B K S, 2008).

Yogic practices have become increasingly popular in western countries as a method for coping with stress and as a means of exercise and fitness training (Schell et al., 1994). Yogic practices are an ancient practice that was developed to promote physical health as well as an awareness of one's true nature. It consists of a series of postures, called asanas, and various breathing exercises, called pranayama, which encourage balance between the physical, mental/emotional, and spiritual aspects of a human being. In short, yogic practices promotes health. Like other forms of yoga, yogic practices is purported to quiet the mind and focus the concentration; however, of all the yoga traditions, the importance of physical fitness is emphasized most in yogic practices (Worthington; 1982).

Yoga has been practiced for thousands of years. It is based on ancient theories, observations and principles of the mind-body connections. Substantial research has been conducted to look at the health benefits of yoga - yoga postures (asanas), yoga breathing (pranayama) and meditation. These yoga practices might be interacting with various somatic and neuro-endocrine mechanisms bringing about therapeutic effects (Malhotra and Singh, 2002). Yoga is traditionally believed to have beneficial effects on physical and emotional health (Gilbert, 1999). The overall performance is known to be improved by practicing yoga techniques (Upadhyay et al., 2008) and their effects on physical functions were reported (Hadi, 2007). Yoga practices can also be used as psycho-physiological stimuli to increase the secretion of melatonin which, in turn, might be responsible for perceived well-being (Harinath et al., 2004). Yoga may be as effective as or better than exercise at improving a variety of health-related outcome measures (Ross and Thomas, 2010).

\section{BENEFITS OF YOGIC PRACTICES}

Yoga has both preventive and therapeutic benefits. It has been shown to offer both physical and mental benefits to the body and the mind. Yogic practices improves flexibility and muscle joint mobility; strengthens, tones and builds muscles; corrects posture; strengthens the spine; eases back pain; improves muscular-skeletal conditions such as bad knees, tight shoulders and neck, sway back and scoliosis; increases stamina; creates balance and grace; stimulates the glands of the endocrine system; improves digestion and elimination; increases circulation; improves heart conditions; improves breathing disorders; boosts immune response; decreases cholesterol and blood sugar levels and encourages weight loss.

\section{MEDITATIONAND THOUGHT WAVES}

People do not enter or exit a running train; they do so only when the train has come to a halt. In the same way, when the mind is deep in thoughts, or engaged in some other activity, the thought waves of the others do not affect it. But when it is static during meditation, the thoughts of the others may find their way into it. It can be avoided through practice. 


\subsubsection{THE BENEFITS OF MEDITATION}

I. Areduction in the frequencies of the mind waves makes it tranquil.

II. The ability to concentrate improves and the mind becomes keen. Integrity and honesty become the qualities of the individual.

III. Sensory perceptions and the working of the mind are halted during meditation, as a result of which biomagnetism is conserved. For example, water in a vessel that is heated over a fire, is converted into steam and escapes from the vessel, leaving the vessel empty, after some time. But if the steam is collected, cooled, and taken back to the vessel through pipes, the level of water in the vessel does not deplete as fast as it normally does. In the same manner, when the mind remains focused on the life energies during meditation, Bio Feedback takes place and biomagnetism is conserved.

IV. The qualities of Perspicacity, Magnanimity, Receptivity, Adaptability and Creativity are improved.

\section{COMPARTION BLOOD}

\section{BLOODS}

Plasma is an electrically neutral medium of unbound positive and negative particles (i.e. the overall charge of a plasma is roughly zero). It is important to note that although the particles are unbound, they are not 'free' in the sense of not experiencing forces. When a charged particle moves, it generates an electric current with magnetic fields; in plasma, the movement of a charged particle affects and is affected by the general field created by the movement of other charges. This governs collective behavior with many degrees of variation. ( Sturrock, Peter A. (1994). Plasma Physics: An Introduction to the Theory of Astrophysical, Geophysical \& Laboratory Plasmas. Cambridge UniversityPress.ISBN 978-0-521-44810-9.)

Hemoglobin is the iron rich protein present in red blood cells of vertebrates and in the tissues of invertebrates. The iron-containing pigment in hemoglobin is called 'hematin' and the protein part is termed as 'globin'. The main function of hemoglobin is to transport oxygen from the lungs to the body tissues, where the oxygen is required to provide energy for the chemical reactions in the living cells. Carbon dioxide, which is released as a byproduct of these chemical reactions is taken back to the lungs for exhalation. As the role of hemoglobin in the human body is vital for leading a healthy life, it is very necessary to maintain its level in the blood.

\section{Hemoglobin Count}

An average male should have a hemoglobin level which ranges between 13.5 to $16.5 \mathrm{~g} / \mathrm{dl}$, while for females it should be within 12.1 to $15.1 \mathrm{~g} / \mathrm{dl}$. For children, a hemoglobin range between 11 to $16 \mathrm{~g} / \mathrm{dl}$ is normal, while for pregnant women, normal hemoglobin level is between 11 to $12 \mathrm{~g} / \mathrm{dl}$. If the level of hemoglobin in the blood is less than normal, then the condition is called anemia. Anemia can be caused by various reasons, the most common being the deficiency of iron. Iron deficiency in the body affects the synthesis of haemoglobin and causes iron deficiency anaemia, which is characterized by smaller red blood cells sans the red pigment - hemoglobin. Iron deficiency may be the result of blood loss through bleeding ulcers or piles, or a diet which is low in iron. Other causes for anemia include problems related to bone marrows, usage of chemotherapy medications, kidney failure, sickle cell anemia, worm infestation, etc. Hemoglobin deficiency results in anemia and can be caused due to various reasons. The treatment of anemia depends on the cause of the disease. In case of iron deficiency anemia, the treatment includes taking iron supplements and food rich in iron. It is believed that iron in food from animal sources is more beneficial in increasing hemoglobin levels than that from plant sources. Shell fish, chicken, liver, beef, red meat, turkey, fish, pork, etc are good sources of iron. Eggs, dark vegetables, green leaves, dried fruits, nuts and beans are also rich in iron.

While taking iron supplements and iron rich food, some food items, which affect the body's ability to absorb iron need to be avoided. These iron-blockers include tea, coffee, foods rich in fiber, foods with high levels of calcium like milk, cheese, chocolate, caffeinated drinks and some medicines with phosphates and antacids. It will be more beneficial if you take vitamin C supplements or foods rich in vitamin C along with the treatment of iron deficiency anemia. Vitamin $\mathrm{C}$ helps in the increased absorption of iron in the body and thereby increases hemoglobin levels. Iron supplements should be taken as per the prescription of your doctor. Some of the iron tablets can cause constipation and stomach upsets. It should not be taken in large quantities, as it can cause an iron overload, which can be toxic for the body. In case of severe anemia, blood transfusions are also suggested for a quick replacement of iron and hemoglobin.

If the reduction in hemoglobin count is due to iron deficiency, then sticking to a diet rich in iron can substantially increase hemoglobin levels. Iron blockers should be avoided and iron supplements and vitamin $\mathrm{C}$ should be taken for better results. The above recommendations will not only solve the problem of how to increase hemoglobin levels, but will also help you lead a healthy life say Sonia Nair.

\section{METHODOLOGY}

The investigator used pre and post test random group design in this study. This procedure involves dividing the sample into two groups based on random selection. The investigator did not make any attempt to equate the groups in this study. The selected forty subjects were divided into two groups consisting of 20 each such as Experimental Group I and a Control Group. The treatment was administered to the experimental groups for a period of sixteen weeks. At the end of $16^{\text {th }}$ week the post test were administered to both the groups.

The haematological variables namely leucocyte count and haemoglobin were selected and tested through TCDC and Shalis blood analyzer test respectively. Pre and post tests were conducted in all the variables. 16 weeks yogic practices were given to the experimental group for a period of 16 weeks. Dependent $t$ test was applied to find out the significant difference between the pre test and the post test.

The following training programme was given for the experimental group for a period of sixteen weeks

\section{THE TRAINING SCHEDULE OF YOGIC PRACTICES IS DIVIDED INTO THREE BLOCKS,}

TABLE - I

(1) The practices for the first five weeks in the Evening (4.45 to 5.45) were as follows:

\begin{tabular}{|c|c|c|c|c|c|}
\hline \multicolumn{6}{|c|}{$\begin{array}{l}\text { Experimental group } \\
\text { yogic Practices }\end{array}$} \\
\hline $\begin{array}{l}\text { S I. } \\
\text { No. }\end{array}$ & $\begin{array}{l}\text { Name of } \\
\text { practice }\end{array}$ & Frequency & \begin{tabular}{|l|} 
Duration \\
of the \\
practice
\end{tabular} & $\begin{array}{l}\text { Rest } \\
\text { time }\end{array}$ & $\begin{array}{l}\text { Total duration } \\
\text { of the practice }\end{array}$ \\
\hline $\mathbf{A}$ & Meditation & & & & \\
\hline 1 & God prayer & 6 days & 1 minute & - & \multirow[t]{5}{*}{20 Minutes $30 \mathrm{sec}$} \\
\hline 2 & Guru worship & 6 days & 1 minute & - & \\
\hline 3 & Kapalatathi & 6 days & 4 minute & - & \\
\hline 4 & Dharava & 6 days & 4 minute & - & \\
\hline 5 & Dhyana & 6 days & 10minutes & $30 \mathrm{sec}$ & \\
\hline B & Yogasana & & & & \\
\hline 1 & $\begin{array}{l}\text { Loosening } \\
\text { exercise }\end{array}$ & 6 days & 2 mintues & $30 \mathrm{sec}$ & \multirow[t]{10}{*}{39 Minutes 30sec } \\
\hline 2 & Vriksasana & 6 days & 4 minutes & $30 \mathrm{sec}$ & \\
\hline 3 & Trikonasana & 6 days & 4 minutes & $30 \mathrm{sec}$ & \\
\hline 4 & Pathahastasana & 6 days & 4 minutes & $30 \mathrm{sec}$ & \\
\hline 5 & $\begin{array}{l}\text { Ardha } \\
\text { chakarasana }\end{array}$ & 6 days & 4 minutes & $30 \mathrm{sec}$ & \\
\hline 6 & Padmasana & 6 days & 4 minutes & $30 \mathrm{sec}$ & \\
\hline 7 & Sugasana & 6 days & 4 minutes & $30 \mathrm{sec}$ & \\
\hline 8 & Yoga mudra & 6 days & 4 minutes & $30 \mathrm{sec}$ & \\
\hline 9 & Matsyasana & 6 days & 4 minutes & $30 \mathrm{sec}$ & \\
\hline \multirow[t]{2}{*}{10} & Savasaana & 6 days & 5 minutes & & \\
\hline & & & & Total & 60 \\
\hline
\end{tabular}

2) Practices for the second five weeks in the Evening (4.45 to 5.45) were as follows; 
Volume-9 | Issue-12 | December - 2019 | PRINT ISSN No. 2249 - 555X | DOI : 10.36106/ijar

TABLE - II

\begin{tabular}{|c|c|c|c|c|c|}
\hline \multicolumn{6}{|c|}{$\begin{array}{l}\text { Experimental group } \\
\text { yogic practice }\end{array}$} \\
\hline SI. No. & Name of practice & Frequency & Duration of the practice & Rest time & Total duration of the practice \\
\hline A & Meditation & & & & \\
\hline 1 & Prayer of god & 6 days & 1 minute & - & \multirow[t]{6}{*}{ 21Minutes $20 \mathrm{sec}$} \\
\hline 2 & Guru worship & 6 days & 1 minute & - & \\
\hline 3 & Nadisudhi & 6 days & 3 minute & - & \\
\hline 4 & Thanduvadasudhi & 6 days & 3 minute & - & \\
\hline 5 & Nama - Rupa meditation & 6 days & 13minutes & $20 \mathrm{sec}$ & \\
\hline B & Asanas practices & & & & \\
\hline 1 & Loosening exercise & 6 days & 2 minutes & $20 \mathrm{sec}$ & \multirow[t]{10}{*}{38 Minutes $40 \mathrm{sec}$} \\
\hline 2 & Dhanurasana & 6 days & 4 minutes & $20 \mathrm{sec}$ & \\
\hline 3 & Sethupandasana & 6 days & 4 minutes & $20 \mathrm{sec}$ & \\
\hline 4 & Ustrasana & 6 days & 4minutes & $20 \mathrm{sec}$ & \\
\hline 5 & Chakarasana & 6 days & 4 minutes & $20 \mathrm{sec}$ & \\
\hline 6 & Adhomuksha svasana & 6 days & 3 minutes & $20 \mathrm{sec}$ & \\
\hline 7 & Salabhasana & 6 days & 3 minutes & $20 \mathrm{sec}$ & \\
\hline 8 & Bhujangasana & 6 days & 3 minutes & $20 \mathrm{sec}$ & \\
\hline 9 & Yogamudra & 6 days & 3 minutes & $20 \mathrm{sec}$ & \\
\hline \multirow[t]{2}{*}{10} & Savasana & 6 days & 5Minutes $40 \mathrm{sec}$ & & \\
\hline & & & & Total & $60 \mathrm{~min}$ \\
\hline
\end{tabular}

Practices for the Third six weeks in the Evening (4.45 to 5.45) were as follows;

TABLE - III

\begin{tabular}{|c|c|c|c|c|c|c|c|c|c|c|c|}
\hline & & & & & $\begin{array}{r}\text { Experim } \\
\text { yogic }\end{array}$ & $\begin{array}{l}\text { tal gr } \\
\text { actic }\end{array}$ & & & & & \\
\hline Sl. No. & Nam & of practice & Freque & ency & Duration of the $p$ & ctice & Sets & & st time & Total duration of the $p$ & oractice \\
\hline $\mathbf{A}$ & Med & ation & & & & & & & & 26 Minutes & \\
\hline 1 & Pray & of god & 6 days & & 1 minute & & & - & & & \\
\hline 2 & Guru & vorship & 6 days & & 1 minute & & & - & & & \\
\hline 3 & Nadi & udhi & 6 days & & 2 minute & & & - & & & \\
\hline 4 & Than & uvadasudhi & 6 days & & 2 minute & & & - & & & \\
\hline 5 & Nam & -Rupa Meditation & 6 days & & 20 minutes & & & & & & \\
\hline B & Yoga & ana & & & & & & & & & \\
\hline & Loos & ning exercise & 6 days & & 2 minutes & & & 10 & $\mathrm{sec}$ & 34 Minutes & \\
\hline 1 & Utka & sana & 6 days & & 5minutes & & 5 times & 50 & $\mathrm{sec}$ & & \\
\hline 2 & Virul & hasan & 6 days & & 1 minutes & & & 10 & $\mathrm{sec}$ & & \\
\hline 3 & Trikc & lasana & 6 days & & 1 minutes & & $1 \mathrm{set}$ & 10 & $\mathrm{sec}$ & & \\
\hline 4 & Pathe & nastasana & 6 days & & 1 minutes & & $1 \mathrm{set}$ & 10 & $\mathrm{sec}$ & & \\
\hline 5 & Ardh & chakarasana & 6 days & & 1 minutes & & $1 \mathrm{set}$ & 10 & $\mathrm{sec}$ & & \\
\hline 6 & Padn & asana & 6 days & & 1 minutes & & $1 \mathrm{set}$ & 10 & $\mathrm{sec}$ & & \\
\hline 7 & Sugh & sana & 6 days & & 1 minutes & & $1 \mathrm{set}$ & 10 & $\mathrm{sec}$ & & \\
\hline 8 & Yoga & nudra & 6 days & & 1 minutes & & $1 \mathrm{set}$ & 10 & $\mathrm{sec}$ & & \\
\hline 9 & Mats & asana & 6 days & & 1 minutes & & $1 \mathrm{set}$ & 10 & $\mathrm{sec}$ & & \\
\hline 10 & Dhan & Irasana & 6 days & & 1 minutes & & $1 \mathrm{set}$ & 10 & $\mathrm{sec}$ & & \\
\hline 11 & Sethı & andasana & 6 days & & 1 minutes & & $1 \mathrm{set}$ & 10 & $\mathrm{sec}$ & & \\
\hline 12 & Ustra & ana & 6 days & & 1 minutes & & 1 set & 10 & $\mathrm{sec}$ & & \\
\hline 13 & Chak & rasana & 6 days & & 1 minutes & & $1 \mathrm{set}$ & 10 & $\mathrm{sec}$ & & \\
\hline 14 & Adhc & nuksha svasana & 6 days & & 1 minutes & & 1 set & 10 & $\mathrm{sec}$ & & \\
\hline 15 & Salap & asana & 6 days & & 1 minutes & & $1 \mathrm{set}$ & 10 & $\mathrm{sec}$ & & \\
\hline 16 & Bhuj & ngasana & 6 days & & 1 minutes & & 1 set & 10 & $\mathrm{sec}$ & & \\
\hline 17 & Utha & apathasana & 6 days & & 1 minutes & & $1 \mathrm{set}$ & 10 & $\mathrm{sec}$ & & \\
\hline 18 & Vipa & takarani & 6 days & & 1 minutes & & $1 \mathrm{set}$ & 10 & $\mathrm{sec}$ & & \\
\hline 19 & Pava & amukthasana & 6 days & & 1 minutes & & $1 \mathrm{set}$ & 10 & $\mathrm{sec}$ & & \\
\hline 20 & Sava & & 6 days & & 5 minutes & & $5 \mathrm{set}$ & & & & \\
\hline & & & & & & & & Tot & tal & $60 \mathrm{~min}$ & \\
\hline VI. RE & TSO & THE STUDY & & & & & & Pre & \begin{tabular}{|l|l|} 
Post & \\
\end{tabular} & \begin{tabular}{|l|l|l|} 
Pre & Post & \\
\end{tabular} & \\
\hline The coll & ed data & were analysed usir & ng depen & ndent $t$ & t and the results & 1 & Haemoglobin & 11.58 & \begin{tabular}{|l|l|}
12.80 & 1.21 \\
\end{tabular} & \begin{tabular}{|l|l|l|}
1.73 & 1.47 & 0.25 \\
\end{tabular} & 4.70 \\
\hline & & & & & & $* \mathrm{Si}$ & nificant at 0.05 & level & & & \\
\hline $\begin{array}{l}\text { TABLE } \\
\text { Mean g } \\
\text { variabl }\end{array}$ & $\begin{array}{l}\text { I } \\
\text { s \& lo } \\
\text { f yogic }\end{array}$ & $\begin{array}{l}\text { es between pre } \\
\text { practice group }\end{array}$ & and pos & t test sc & ores on selected & & $\begin{array}{l}\text { xamination of } \\
\& 4.47 \text { for hem } \\
\text { ted variables }\end{array}$ & $\begin{array}{l}\text { table- } \\
\text { noglobi } \\
\text { were fo }\end{array}$ & $\begin{array}{l}\text { II indicates } \\
\text { in respectiv } \\
\text { ound to be }\end{array}$ & $\begin{array}{l}\text { s that the obtained't' rat } \\
\text { vely. The obtained't' rati } \\
\text { greater than the requil }\end{array}$ & $\begin{array}{l}\text { tios were } \\
\text { os on the } \\
\text { red table }\end{array}$ \\
\hline \begin{tabular}{|l|l} 
S. & V \\
No &
\end{tabular} & ibles & \begin{tabular}{|l|l|} 
Mean & $\begin{array}{l}\text { Me } \\
\text { difi }\end{array}$ \\
\end{tabular} & $\begin{array}{l}\text { ean } \\
\text { fference }\end{array}$ & SD ( $( \pm)$ & $\mid \sigma$ DM $\left|\begin{array}{c}\text { t } \\
\text { Ratio }\end{array}\right|$ & $\begin{array}{l}\text { valy } \\
\text { So i } \\
\text { stati }\end{array}$ & $\begin{array}{l}\text { of } 2.861 \text { at } 0.0 \\
\text { was found to bc } \\
\text { tically significa }\end{array}$ & $\begin{array}{l}05 \text { leve } \\
\text { e signi } \\
\text { ant and }\end{array}$ & $\begin{array}{l}1 \text { of signific } \\
\text { ficant. The } \\
\text { explained i }\end{array}$ & $\begin{array}{l}\text { cance for } 19 \text { degrees of } \\
\text { results of this study sho } \\
\text { its effects positively. }\end{array}$ & $\begin{array}{l}\text { freedom. } \\
\text { owed that }\end{array}$ \\
\hline
\end{tabular}


TABLE - III Significance of mean gains \& losses between pre and post test scores on selected variables of control group

\begin{tabular}{|c|c|c|c|c|c|c|c|c|}
\hline \multirow{2}{*}{$\begin{array}{l}\text { S. } \\
\text { No }\end{array}$} & \multirow[t]{2}{*}{ Variables } & \multicolumn{2}{|l|}{ Mean } & \multirow{2}{*}{\begin{tabular}{l|} 
Mean \\
difference
\end{tabular}} & \multicolumn{2}{|c|}{$\mathrm{SD}( \pm)$} & \multirow[t]{2}{*}{$\sigma \mathrm{DM}$} & \multirow[t]{2}{*}{ 't' Ratio } \\
\hline & & Pre & Post & & Pre & Post & & \\
\hline 1 & Hemoglobin & 12.25 & 12.07 & 0.18 & 1.94 & 1.62 & 0.13 & 1.32 \\
\hline
\end{tabular}

An examination of table-II indicates that the obtained't' ratios were $0.089 \& 1.32$ for, haemoglobin respectively. The obtained't' ratios on the selected variables were found to be lesser than the required table value of 2.861 at 0.05 level of significance for 19 degrees of freedom. So it was found to be insignificant.

\section{DISCUSSION ON THE FINDINGS}

The prime intention of the researcher was to analyse the effect of yogic practices on selected haemoglobin variables among college women. The yogic practices group had significantly improved in haemoglobin.

Yogic practices help women to maintain their health and wellness. The below mentioned study is a research Geetha.K (2014) found out the Effect of Yogic practices on selected hematological variables among college girls suffering with ir menstruation. The study involved 60 subjects under the age group of 16 to 21 years. Experimental group I \& II underwent training for 12 weeks. The control group was kept in active rest. Analysis of co-variance (ANCOVA) to determine the significant difference and tested at 0.05 level of significance. The result of the study showed that the Glucose tolerance and total cholesterol were significantly reduced as result of Yogic practices.

\section{CONCLUSION}

Within the limitations and on the basis of the findings of the study, it was very clear that sixteen weeks of simple Yogic practices and Meditation produced significant changes in haemoglobin of college women students.

\section{REFERENCES:}

1. Vimla Lalvani, 2003. The Power of Yoga.
2. Author Swami Adiswarananda, A Guide to the spiritual paths of Action, Devotion, Author Swami Adiswarananda, A Guide to the spiritual paths of Action, Devotion,
Meditation and knowledge.(PG18); published by the president Sri Ramakrishna Math,Mylapore, Chennai-4

3. Cole, Roger. Physiology of yoga. Ingra Yoga Institute Review, Oct 1985. $f$ Corby, J. C., W. T. Roth, V. P. Zarcone, Jr., and B. S. Kopell. Psychophysiological correlates of the practice of Tantric Yoga meditation. Archives of General Psychiatry, May 1978, 35(5):571-577. $f$

4. Iyengar, BKS (2008), Light on Yoga Published by An imprint of Harper Collins Publishers India Pvt. Ltd., New Delhi P.20.

5. Sharma, P.D (1984). Yogasana and pranayama for health. Navneet Publicans, 10-11.

6. Swamy Sivananda (1935). Yoga Teachers Manual Pub International Vendanta Centers, Valmorin, Quebic, Canada The Complete books of yoga: Harmony of body and mind Valmorin, Quebic, Canada The Complete
Orient paper Backs: Vision Book pvt. Ltd.

7. World Health Organization. (2009). "Women and health: today's evidence tomorrow's agenda."

8. Worthington VA. (1982) History of Yoga. London. UK: Routledge and Kegan Paul, 1982 .

9. Yogi Bhajan. (2016). The Aquarian Teacher, KRI International Teacher Training in Kundalini Yoga as taught by Yogi Bhajan, Kundalini Research Institute, 4th Edition.

10. Bal, B.S., Kaur, P.J. (2009) Effects of selected asanas in hatha yoga on agility and flexibility level. Journal of Sport and Health Research. 1(2):75-87.

11. Gilbert C. (1999). Yoga and Breathing. J. Bodywork Mov. Ther. 3:44-54. 9. 